\title{
EFFECT OF NITROGEN AND OFF SEASON BULB SIZE ON ONION SEED PRODUCTION
}

\author{
M. Basnet ${ }^{1}$, S.M. Shakya ${ }^{1}$, S.M. Shrestha ${ }^{1}$ and K. Mishra ${ }^{3}$ \\ ${ }^{1}$ Nepal Agriculture Research Council, Kathmandu, Nepal, \\ ${ }^{2}$ Institute of Agriculture and Animal Sciences, Tribhuvan University, Nepal, \\ ${ }^{3}$ Agriculture and Forestry University, Chitwan, Nepal
}

\begin{abstract}
An experiment was conducted at Sukranagar, Chitwan to assess the effect of nitrogen $(\mathrm{N})$ and off season bulb size on seed production of onion cv. Bemausami-1 (N-8293) during 2009/10. Five levels of nitrogen $(0,40,80,120$ and $160 \mathrm{~kg} \mathrm{~N} / \mathrm{ha})$ as main plot factor and three bulb size $(<1,1-3$ and $>3 \mathrm{~cm}$ diameter $)$ as sub plot factor were used as treatments and laid out in a split plot design with three replications. Plant height, number of tillers, leaves; scapes, umbels, and flowers per plant were significantly high at higher doses of nitrogen and similar results were found at the bigger sized bulb too. Seed yield was the highest $(300.2 \mathrm{~kg} / \mathrm{ha})$ at $160 \mathrm{~kg} \mathrm{~N} / \mathrm{ha}$ and $>3 \mathrm{~cm}$ bulb size and the lowest $(200.1 \mathrm{~kg} / \mathrm{ha})$ at $0 \mathrm{~kg} \mathrm{~N} / \mathrm{ha}$ and $<1 \mathrm{~cm}$ bulb size. B: C ratio was the highest (1.79) at $160 \mathrm{~kg} \mathrm{~N} / \mathrm{ha}$ with medium sized bulb (1-3 cm) and the lowest (1.05) at $0 \mathrm{~kg}$ $\mathrm{N} / \mathrm{ha}$ with bulb size of $<1 \mathrm{~cm}$.
\end{abstract}

Key words: vegetable, storage, export and import

\section{INTRODUCTION}

Onion, the important spice crop in Allium, ranks third in production among the vegetable crops in the world after tomato and cabbage (FAO, 1996) and second in area under cultivation among the major vegetables and spices after tomato (Pathak, 1994). Thapa and Paudyal (2000) reported that it ranked 4th position among vegetables in terms of its volume and value of the production in Nepal. There is steady demand of onion bulb throughout the year which is increasing every year in Nepal. Severe scarcity of onion bulbs is seen from August to March in the vegetable markets of Nepal which is fulfilled by import from India in the period (Budhathoki et al., 2004). Nepal invested NRs. $49,93,23,487$ to import 4,85,86,882 $\mathrm{kg}$ onion and shallot during 2008/09 (NFTS, 2009). Though Nepal is rich in agro-ecological, climatic, topographical and edaphic variation, it is still far behind to fulfill the seed demanded. However, Rukum district producing $200 \mathrm{~kg}$ onion seed (VDD, 2009) and $135 \mathrm{~kg}$ seed produced at Citrus Development Centre, Palpa (Mr. Buddhi Prakash Ghimire, Planning officer, DADO) but this amount is far beyond to meet the national demand of $1932 \mathrm{mt}$ of onion seed. We are dependent on the seed business to foreign country. The total amount of vegetables seed including onion imported was about 2,49,643 kg which was worth NRs 6,84,65,620 (NFTS, 2008/09).Moreover, onion bulbs require vernalization for flowering, thus bulbs produced during February needs to be stored until the commencement of the cold season. There is a huge problem on storing the bulb at our country and is also a tedious job. In addition, this research will also assist on coping the storage problems and to make the seeds available throughout the year this study was carried out by using the off season bulb size since these bulbs have been harvested during November and are directly transplanted for seed production.

Nitrogen is the major factor governing seed yield and quality of onion. El Hilo et al. (1971) reported that the lack of nitrogen induced yellowing of leaves and flower stalks and caused burning of leaf tips, in contrast to plants treated with nitrogen which remained green throughout the growing season. They also reported that nitrogen fertilizer application resulted in high total nitrogen content in the leaves. Nourai et al. (2003) attributed the increase in seed yield due to the increase in seed 
yield of individual plants in response to increased level of nitrogen (150 kg N/ha). Similarly, bulb size generally plays an important role in seed production. Mishra (1994) obtained $659.74 \mathrm{~kg} / \mathrm{ha}$ seed from onion plants grown from larger bulbs (3.5-4.5 cm diameter) compared to smaller bulbs (1.5-2.5 $\mathrm{cm}$ diameter). Best seed yields were obtained from plants grown from larger bulbs as compared to medium and small sizes. A larger mother bulb having a larger food supply and water content than the other sizes enabled the development of vigorous plants and production of higher seed yields (Levy et al., 1981).

\section{METHODOLOGY}

The experiment was laid out in a Split Plot Design. The main factor was five doses of nitrogen $(0,40,80,120$, and $160 \mathrm{~kg} / \mathrm{ha})$ and subplot factor was three levels of bulb diameter: small $(<1 \mathrm{~cm})$, medium (1-3 cm), and large $(>3 \mathrm{~cm})$. There were 15 treatments which were replicated thrice. Plots were assigned randomly within each main plot. The bulbs were planted at $45 \times 30 \mathrm{~cm}$ on every sub plot size having 4 rows with 5 plants per row on the area of $2.7 \mathrm{~m} 2$. There were 20 plants per sub plot which were categorized as inner 6 observational plants and other remaining 14 boarder plants.

Each plot was supplied with well rotted FYM, Phosphorous, potassium at 20000: 60:60 kg/ ha as basal dose whereas, the nitrogen was applied at different doses $(0,40,80,120$ and $160 \mathrm{~kg} / \mathrm{ha})$. Half of the nitrogen and full dose of FYM, phosphorus $(60 \mathrm{~kg} / \mathrm{ha})$ and potassium $(60 \mathrm{~kg} / \mathrm{ha})$ were applied as basal dose before transplanting. Rest half of nitrogen was top-dressed at 50 days after transplantation. Nitrogen was supplied through Urea $(46 \% \mathrm{~N})$ and DAP, phosphorus through DAP $(18 \% \mathrm{~N}$ and $46 \% \mathrm{P})$ and potash through Murate of potash $(60 \% \mathrm{~K})$. The field was irrigated at 7 days interval and was reduced during seed maturity stage. The onion seeds were harvested by cutting the umbel along with $10-15 \mathrm{~cm}$ stalk for easy handling when $10 \%$ of the head showed black color. The seeds were threshed and dried up to safe moisture level.

\section{RESULTS AND DISCUSSION \\ Plant height, number of tillers and leaves per plant}

The maximum plant height of onion was found at Nitrogen level $160 \mathrm{~kg} / \mathrm{ha}(45.32,49.54 \mathrm{and}$ $55.26 \mathrm{~cm}$ )and at $>3 \mathrm{~cm}$ bulb size $(41.01,44.96$ and $49.62 \mathrm{~cm})$ at 45,60 and 75 days after planting (DAP) respectively. Similarly, the maximum number of tillers were found at $160 \mathrm{~kg} \mathrm{~N} / \mathrm{ha}(1.53,2.12$ and 2.27) and at $>3 \mathrm{~cm}$ bulb size $(1.60,2.05$ and 2.18) at 60, 75 and 90 DAP respectively. Moreover, the maximum number of leaves were found at $160 \mathrm{~kg} \mathrm{~N} / \mathrm{ha}(13.69,14.85,16.78$ and 9.01) and at $>3$ cm bulb size $(10.80,12.05,12.94$ and 8.15$)$ at $60,75,90$ and 105 DAP respectively (Table 1). There was significant interaction effect of nitrogen level and bulb size on plant height at 45, 60 and 75 DAP and on number of tillers at 60 DAP (Figure 2 and 3). Dahal (2008) and Shakya (2009) reported the plant height which were in agreement with the results obtained. The largest bulb produced the tallest plant followed by medium and smallest bulb (Khan et al., 2005). Nitrogen is a constituent of proteins, enzymes, hormones, vitamins alkaloids, chlorophyll and photosynthesis which led to an increment in plant metabolism and vegetative growth expressed as plant heights, number of leaves per plant, both length and diameter of leaves, leaf area and crop (Kumar et al., and Al-Moshileh et al.,2002). Due to the higher dose of nitrogen $(150 \mathrm{~kg} / \mathrm{ha})$ the vegetative growth of onion plant was increased which helped to increase the number of tillers per plant (Rahim et al., 1997). Ambulkar et al. (1995) and Hussain et al. (2001) recorded more number of leaves from large sized bulb $(5.5-5.99 \mathrm{~cm})$. 

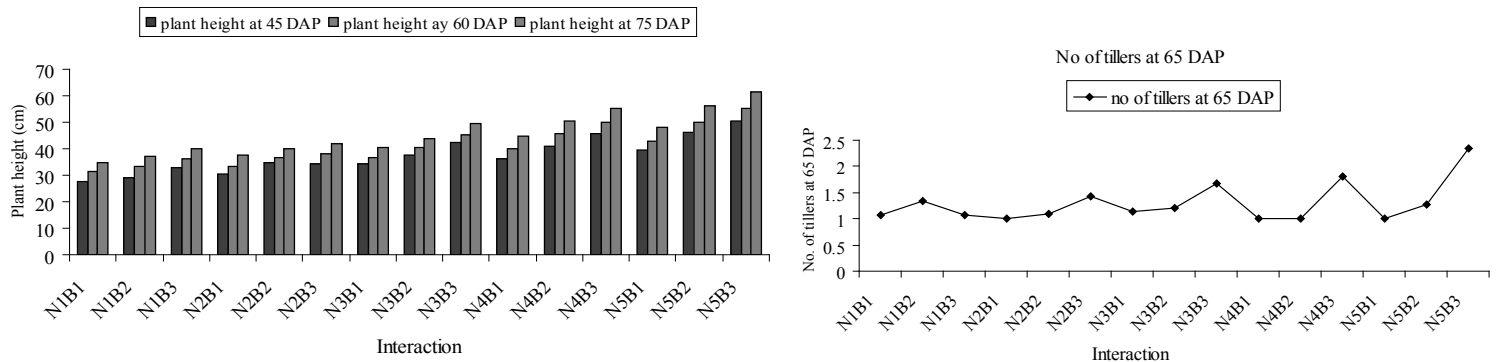

Figure 2 and 3. Interaction effect of nitrogen and bulb size on periodic plant height and number of tillers per plant of onion at Sukranagar, Chitwan, Nepal, 2009/10.

\section{Number of scape, umbels, flowers per plant and seed yield in onion plant}

The number of scape per plant was significantly the highest at nitrogen level $160 \mathrm{~kg} / \mathrm{ha}(1.95$, 2.56 and 1.61) and at $>3 \mathrm{~cm}$ bulb size $(1.45,2.06$ and 1.30) at 75,85 and 95 days after planting (DAP) respectively. Similarly, the number of umbels per plant was significantly the highest at nitrogen level $160 \mathrm{~kg} / \mathrm{ha}(2.83,2.40$ and 2.90) and at $>3 \mathrm{~cm}$ bulb size $(3.16,2.57$ and 2.64) at 85, 95 and 105 days after planting (DAP) respectively. Likewise the number of flowers per plant and seed yield was significantly the highest at nitrogen level $160 \mathrm{~kg} / \mathrm{ha}(668.4$ and $278.5 \mathrm{~kg} / \mathrm{ha})$ and at $>3 \mathrm{~cm}$ bulb size (719.0 and $244.3 \mathrm{~kg} / \mathrm{ha}$ ) respectively (Table 2). Moreover, lowest number of scape, umbels, flowers per plant and seed yield was found at at $0 \mathrm{~kg} \mathrm{~N} / \mathrm{ha}$ and $<1 \mathrm{~cm}$ bulb size. There was significant interaction effect of nitrogen level and bulb size on seed yield of onion(Figure 4).Mishra (1994) noticed greater number of scape and umbel per plant at $150 \mathrm{~kg} \mathrm{~N} / \mathrm{ha}$ and Farag and Koriem (1996) recorded the highest number of scapes and umbels per plant on $>5 \mathrm{~cm}$ bulb size while the lowest at $<1 \mathrm{~cm}$ diameter.

Table 1. Periodic plant height, number of tillers and leaves per plant at different doses of nitrogen and bulb size at Sukranagar, Chitwan, Nepal, 2009/10

\begin{tabular}{|c|c|c|c|c|c|c|c|c|c|c|}
\hline \multirow{2}{*}{ Treatments } & \multicolumn{3}{|c|}{ Plant height $(\mathrm{cm})$} & \multicolumn{3}{|c|}{ Number of tillers per plant } & \multicolumn{4}{|c|}{ Number of leaves per plant } \\
\hline & 45 DAP & 60 DAP & 75 DAP & 60 DAP & 75 DAP & 90 DAP & 60 DAP & 75 DAP & 90 DAP & 105 DAP \\
\hline \multicolumn{11}{|c|}{ Nitrogen (Main factor) } \\
\hline $\mathrm{N}_{1}(0 \mathrm{~kg} \mathrm{~N} / \mathrm{ha})$ & $29.75^{\mathrm{e}}$ & $33.65^{\mathrm{e}}$ & $37.32^{\mathrm{e}}$ & $1.15^{b}$ & $1.22^{\mathrm{d}}$ & $1.33^{\mathrm{c}}$ & $6.48^{\mathrm{e}}$ & $7.29^{\mathrm{e}}$ & $8.01^{\mathrm{e}}$ & $6.25^{\mathrm{d}}$ \\
\hline $\mathrm{N}_{2}(40 \mathrm{~kg} \mathrm{~N} / \mathrm{ha})$ & $32.97^{\mathrm{d}}$ & $35.98^{d}$ & $39.95^{\mathrm{d}}$ & $1.17^{\mathrm{b}}$ & $1.62^{\mathrm{c}}$ & $1.72^{b}$ & $8.27^{\mathrm{d}}$ & $8.95^{\mathrm{d}}$ & $9.74^{\mathrm{d}}$ & $6.56^{\mathrm{d}}$ \\
\hline $\mathrm{N}_{3}(80 \mathrm{~kg} \mathrm{~N} / \mathrm{ha})$ & $38.07^{\mathrm{c}}$ & $40.65^{\mathrm{c}}$ & $44.63^{c}$ & $1.33^{\mathrm{ab}}$ & $1.55^{\mathrm{c}}$ & $1.67^{b}$ & $9.62^{\mathrm{c}}$ & $11.02^{\mathrm{c}}$ & $11.60^{\mathrm{c}}$ & $7.33^{\mathrm{c}}$ \\
\hline $\mathrm{N}_{4}(120 \mathrm{~kg} \mathrm{~N} / \mathrm{ha})$ & $40.92^{b}$ & $45.37^{b}$ & $50.16^{\mathrm{b}}$ & $1.26^{\mathrm{b}}$ & $1.84^{\mathrm{b}}$ & $1.94^{\mathrm{b}}$ & $11.08^{b}$ & $12.35^{b}$ & $13.74^{\mathrm{b}}$ & $7.99^{b}$ \\
\hline $\mathrm{N}_{5}(160 \mathrm{~kg} \mathrm{~N} / \mathrm{ha})$ & $45.32^{\mathrm{a}}$ & $49.54^{\mathrm{a}}$ & $55.26^{\mathrm{a}}$ & $1.53^{\mathrm{a}}$ & $2.12^{\mathrm{a}}$ & $2.27^{\mathrm{a}}$ & $13.69^{\mathrm{a}}$ & $14.85^{\mathrm{a}}$ & $16.78^{a}$ & $9.01^{\mathrm{a}}$ \\
\hline $\mathrm{SE}_{\mathrm{m}}$ & 0.55 & 0.58 & 0.69 & 0.06 & 0.05 & 0.10 & 0.11 & 0.09 & 0.18 & 0.12 \\
\hline LSD & 1.81 & 1.89 & 2.26 & 0.22 & 0.18 & 0.32 & 0.37 & 0.31 & 0.61 & 0.41 \\
\hline $\mathrm{CV} \%$ & 6.21 & 8.86 & 9.75 & 14.14 & 9.34 & 10.43 & 6.01 & 5.27 & 9.57 & 10.80 \\
\hline \multicolumn{11}{|c|}{ Bulb size (Sub factor) } \\
\hline $\mathrm{B}_{1}(<1 \mathrm{~cm})$ & $33.55^{c}$ & $36.88^{c}$ & $41.15^{\mathrm{c}}$ & $1.04^{\mathrm{c}}$ & $1.35^{\mathrm{c}}$ & $1.45^{\mathrm{c}}$ & $9.08^{c}$ & $9.90^{\mathrm{c}}$ & $10.82^{\mathrm{c}}$ & $6.65^{c}$ \\
\hline $\mathrm{B}_{2}(1-3 \mathrm{~cm})$ & $37.66^{\mathrm{b}}$ & $41.27^{\mathrm{b}}$ & $45.61^{b}$ & $1.18^{\mathrm{b}}$ & $1.61^{\mathrm{b}}$ & $1.74^{\mathrm{b}}$ & $9.61^{b}$ & $10.72^{b}$ & $12.15^{\mathrm{b}}$ & $7.48^{b}$ \\
\hline $\mathrm{B}_{3}(>3 \mathrm{~cm})$ & $41.01^{\mathrm{a}}$ & $44.96^{\mathrm{a}}$ & $49.62^{\mathrm{a}}$ & $1.60^{\mathrm{a}}$ & $2.05^{\mathrm{a}}$ & $2.18^{\mathrm{a}}$ & $10.80^{\mathrm{a}}$ & $12.05^{\mathrm{a}}$ & $12.94^{\mathrm{a}}$ & $8.15^{\mathrm{a}}$ \\
\hline $\mathrm{SE}_{\mathrm{m}}$ & 0.31 & 0.40 & 0.44 & 0.04 & 0.04 & 0.04 & 0.07 & 0.09 & 0.11 & 0.07 \\
\hline LSD & 0.91 & 1.20 & 1.29 & 0.13 & 0.11 & 0.14 & 0.22 & 0.27 & 0.32 & 0.21 \\
\hline $\mathrm{CV} \%$ & 6.21 & 8.86 & 9.75 & 14.14 & 9.34 & 10.43 & 6.01 & 5.27 & 9.57 & 10.80 \\
\hline
\end{tabular}

$\mathrm{DAP}=$ Days after planting of the bulb, $\mathrm{N}_{1} \mathrm{~N}_{2} \mathrm{~N}_{3} \mathrm{~N}_{4}$ and $\mathrm{N}_{5}$ represents $0,40,80,120$ and $160 \mathrm{~kg} \mathrm{~N} /$ ha respectively and $\mathrm{B}_{1}, \mathrm{~B}_{2}$ and $\mathrm{B} 3$ represents $<1 \mathrm{~cm}, 1-3 \mathrm{~cm}$ and $>3 \mathrm{~cm}$ bulb size respectively. Treatment means followed by common letter (s) are not significantly different from each other based on DMRT at 5\% level of significance 
Table 2. Number of scape, umbels, flowers per plant and seed yield in onion at periodic stages of growth at different doses of nitrogen and bulb size at Sukranagar, Chitwan, Nepal, 2009/10

\begin{tabular}{|c|c|c|c|c|c|c|c|c|}
\hline \multirow{2}{*}{ Treatments } & \multicolumn{3}{|c|}{ Number of scapes per plant } & \multicolumn{3}{|c|}{ Number of umbels per plant } & \multirow{2}{*}{$\begin{array}{l}\text { Number of flowers per } \\
\text { plant } \\
95 \text { DAP }\end{array}$} & \multirow{2}{*}{$\frac{\text { Seed yield }}{\mathrm{Kg} / \mathrm{ha}}$} \\
\hline & 75 DAP & 85 DAP & 95 DAP & 85 DAP & 95 DAP & 105 DAP & & \\
\hline \multicolumn{9}{|c|}{ Nitrogen (Main factor) } \\
\hline $\mathrm{N}_{1}(0 \mathrm{~kg} \mathrm{~N} / \mathrm{ha})$ & $0.52^{\mathrm{e}}$ & $0.94^{\mathrm{e}}$ & $0.45^{\mathrm{e}}$ & $0.83^{\mathrm{e}}$ & $1.21^{\mathrm{d}}$ & $1.38^{\mathrm{d}}$ & $324.6^{\mathrm{b}}$ & $211.9^{c}$ \\
\hline $\mathrm{N}_{2}(40 \mathrm{~kg} \mathrm{~N} / \mathrm{ha})$ & $0.81^{\mathrm{d}}$ & $1.31^{\mathrm{d}}$ & $0.66^{\mathrm{d}}$ & $1.53^{\mathrm{d}}$ & $1.62^{\mathrm{c}}$ & $1.76^{\mathrm{c}}$ & $491.0^{\mathrm{ab}}$ & $216.6^{\mathrm{c}}$ \\
\hline $\mathrm{N}_{3}(80 \mathrm{~kg} \mathrm{~N} / \mathrm{ha})$ & $1.03^{\mathrm{c}}$ & $1.62^{\mathrm{c}}$ & $1.05^{\mathrm{c}}$ & $1.84^{\mathrm{c}}$ & $1.73^{\mathrm{c}}$ & $1.83^{\mathrm{c}}$ & $561.8^{\mathrm{a}}$ & $220.4^{\mathrm{c}}$ \\
\hline $\mathrm{N}_{4}(120 \mathrm{~kg} \mathrm{~N} / \mathrm{ha})$ & $1.51^{\mathrm{b}}$ & $2.02^{b}$ & $1.36^{\mathrm{b}}$ & $2.24^{\mathrm{b}}$ & $2.06^{\mathrm{b}}$ & $2.51^{\mathrm{b}}$ & $543.6^{\mathrm{a}}$ & $241.7^{b}$ \\
\hline $\mathrm{N}_{5}(160 \mathrm{~kg} \mathrm{~N} / \mathrm{ha})$ & $1.95^{\mathrm{a}}$ & $2.56^{\mathrm{a}}$ & $1.61^{\mathrm{a}}$ & $2.83^{\mathrm{a}}$ & $2.40^{\mathrm{a}}$ & $2.90^{\mathrm{a}}$ & $668.4^{\mathrm{a}}$ & $278.5^{\mathrm{a}}$ \\
\hline$\overline{\mathrm{SE}_{\mathrm{m}}}$ & 0.04 & 0.04 & 0.03 & 0.07 & 0.06 & 0.07 & 59.76 & 5.20 \\
\hline LSD & 0.14 & 0.15 & 0.10 & 0.25 & 0.22 & 0.25 & 194.9 & 16.98 \\
\hline $\mathrm{CV} \%$ & 13.79 & 6.62 & 10.17 & 14.22 & 9.92 & 9.54 & 15.83 & 2.11 \\
\hline \multicolumn{9}{|c|}{ Bulb size (Sub factor) } \\
\hline $\mathrm{B}_{1}(<1 \mathrm{~cm})$ & $0.87^{\mathrm{c}}$ & $1.34^{\mathrm{c}}$ & $0.73^{\mathrm{c}}$ & $0.90^{\mathrm{c}}$ & $1.22^{\mathrm{c}}$ & $1.50^{\mathrm{c}}$ & $344.4^{\mathrm{c}}$ & $218.8^{c}$ \\
\hline $\mathrm{B}_{2}(1-3 \mathrm{~cm})$ & $1.17^{\mathrm{b}}$ & $1.67^{\mathrm{b}}$ & $1.06^{\mathrm{b}}$ & $1.50^{\mathrm{b}}$ & $1.62^{\mathrm{b}}$ & $2.09^{b}$ & $490.2^{b}$ & $238.3^{b}$ \\
\hline $\mathrm{B}_{3}(>3 \mathrm{~cm})$ & $1.45^{\mathrm{a}}$ & $2.06^{\mathrm{a}}$ & $1.30^{\mathrm{a}}$ & $3.16^{\mathrm{a}}$ & $2.57^{\mathrm{a}}$ & $2.64^{\mathrm{a}}$ & $719.0^{\mathrm{a}}$ & $244.3^{\mathrm{a}}$ \\
\hline$\overline{\mathrm{SE}_{\mathrm{m}}}$ & 0.04 & 0.02 & 0.02 & 0.06 & 0.04 & 0.05 & 21.16 & 1.27 \\
\hline LSD & 0.12 & 0.08 & 0.79 & 0.20 & 0.13 & 0.15 & 62.43 & 3.754 \\
\hline $\mathrm{CV} \%$ & 13.79 & 6.62 & 10.17 & 14.22 & 9.92 & 9.54 & 15.83 & 2.11 \\
\hline
\end{tabular}

$\mathrm{DAP}=$ Days after planting of the bulb, $\mathrm{N}_{1} \mathrm{~N}_{2} \mathrm{~N}_{3} \mathrm{~N}_{4}$ and $\mathrm{N}_{5}$ represents $0,40,80,120$ and $160 \mathrm{~kg}$ $\mathrm{N} /$ ha respectively and $\mathrm{B}_{1}, \mathrm{~B}_{2}$ and $\mathrm{B} 3$ represents $<1 \mathrm{~cm}, 1-3 \mathrm{~cm}$ and $>3 \mathrm{~cm}$ bulb size respectively. Treatment means followed by common letter (s) are not significantly different from each other based on DMRT at 5\% level of significance.

Nehra et al. (1989) noticed the greatest number of flowers per plant emerged from large sized bulbs. Bhardwaj et al. (1991) and Patel and Vachhani (1994) also reported the greater number of flowers per plant at $150 \mathrm{~kg} \mathrm{~N} / \mathrm{ha}$. Ali et al. (1998) reported that $5.5-7 \mathrm{~cm}$ bulb produced significantly high seed yield as compared to the $>1 \mathrm{~cm}$.

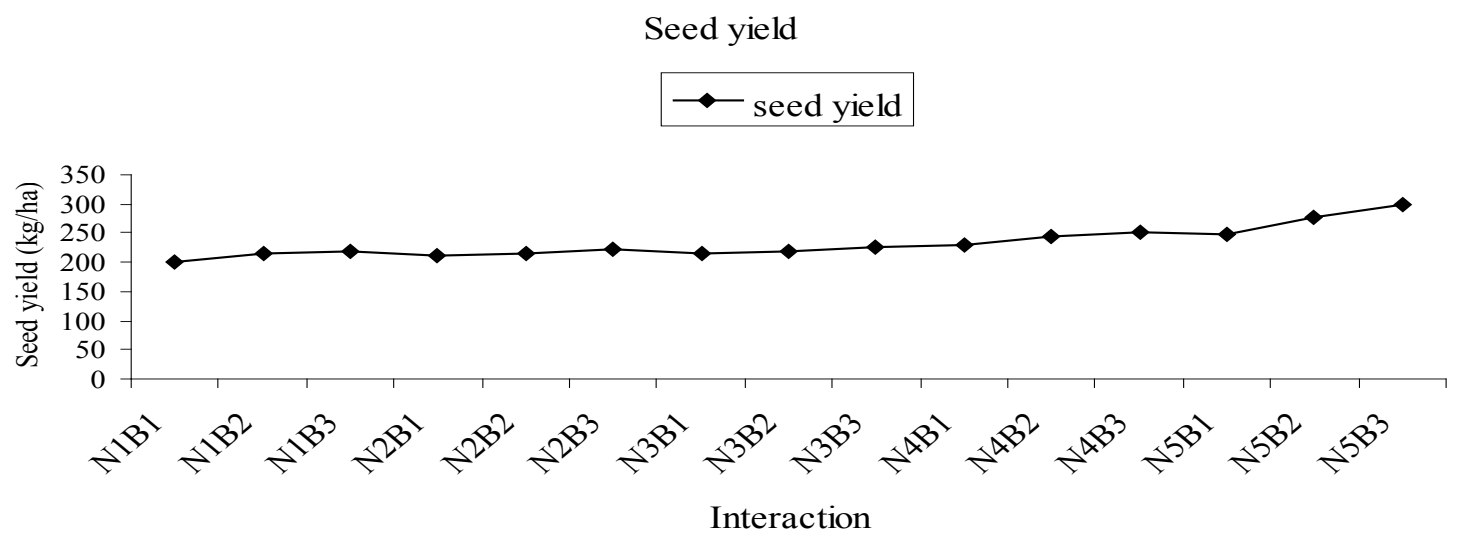

Figure 4. Interaction effect of nitrogen and bulb size on seed yield (kg/ha) of onion at Sukranagar, Chitwan, 2009/10. 
Table 3. Economic analysis of seed production of onion at different doses of nitrogen and bulb size at Sukranagar, Chitwan, 2009/10

\begin{tabular}{lllllll}
\hline Treatment & $\begin{array}{l}\text { Seed yield } \\
\text { (kg/ha) }\end{array}$ & $\begin{array}{l}\text { Rate of bulb } \\
\text { (N Rs/kg) }\end{array}$ & $\begin{array}{l}\text { Gross } \\
\text { income } \\
\text { (NRs/ha) }\end{array}$ & $\begin{array}{l}\text { Total } \\
\text { production } \\
\text { cost (NRs/ } \\
\text { ha) }\end{array}$ & $\begin{array}{l}\text { Net return } \\
\text { (NRs/ha) }\end{array}$ & B/C ratio \\
\hline N1 B1 & 200.2 & 1000 & 200200 & 141324 & 58876 & 1.41 \\
N1 B2 & 215.3 & 1000 & 215300 & 160372 & 54928 & 1.34 \\
N1 B3 & 220.4 & 1000 & 220400 & 207991 & 12409 & 1.05 \\
N2 B1 & 210.2 & 1000 & 210200 & 142444 & 67756 & 1.47 \\
N2 B2 & 216.8 & 1000 & 216800 & 161492 & 55308 & 1.34 \\
N2 B3 & 222.6 & 1000 & 222600 & 209111 & 13489 & 1.06 \\
N3 B1 & 213.5 & 1000 & 213500 & 143564 & 69936 & 1.48 \\
N3 B2 & 220 & 1000 & 220000 & 162612 & 57388 & 1.35 \\
N3 B3 & 227.6 & 1000 & 227600 & 210231 & 17369 & 1.08 \\
N4 B1 & 230.4 & 1000 & 230400 & 144684 & 85716 & 1.59 \\
N4 B2 & 244.3 & 1000 & 244300 & 163732 & 80568 & 1.49 \\
N4 B3 & 250.5 & 1000 & 250500 & 211351 & 39149 & 1.18 \\
N5 B1 & 240 & 1000 & 248000 & 145804 & 94196 & 1.64 \\
N5 B2 & 295.23 & 1000 & 295230 & 164852 & 130378 & 1.79 \\
N5 B3 & 300.2 & 1000 & 300200 & 212471 & 87729 & 1.41 \\
\hline
\end{tabular}

Though the production was the highest at $160 \mathrm{~kg} \mathrm{~N} / \mathrm{ha}$ and bulb size of $>3 \mathrm{~cm}$ diameter but its $\mathrm{B} / \mathrm{C}$ ratio was lower as compared to $160 \mathrm{~kg} \mathrm{~N} / \mathrm{ha}$ and bulb size of 1-3 cm diameter since high investment was required to purchase larger bulb as compared to other bulbs (Table 3). Thus it is economical to use medium i.e. 1-3 cm bulb size for onion seed production. Jilani (2004), Mirshekari et al., (2008), and Mosleh ud- Deen (2008) also reported the similar results.

\section{CONCLUSION}

The parameters i.e. plant height, number of leaves, number of tillers, number of scapes, number of umbels, number of flowers per plant and seed yield was found to be highest at $160 \mathrm{~kg} / \mathrm{ha}$ and $>3$ $\mathrm{cm}$ diameter bulb. But, from the economic analysis of seed production of onion, $\mathrm{B} / \mathrm{C}$ ratio was the highest (1.79) at $160 \mathrm{~kg} \mathrm{~N} /$ ha and $1-3 \mathrm{~cm}$ i.e. medium bulb size with the lowest $\mathrm{B} / \mathrm{C}(1.059)$ at $0 \mathrm{~kg}$ $\mathrm{N} / \mathrm{ha}$ and $>3 \mathrm{~cm}$ bulb size. Thus, it is recommended $160 \mathrm{~kg} \mathrm{~N} / \mathrm{ha}$ and bulb of $1-3 \mathrm{~cm}$ size would be suitable combination for the seed production of onion for export promotion and import substitution of the crop.

\section{ACKNOWLEDGEMENTS}

The authors express their sincere thanks to National Agriculture Research Development Fund for providing financial support and Directorate of Research of the Institute of Agriculture and Animal Sciences, Rampur, Chitwan, Nepal for timely providing necessary facilities and logistic supports.

\section{REFERENCES CITED}

Al-Moshileh, A.M. 2002. Effect of rate and time of nitrogen application on onion production in the central region of Saudi Arabia. J. Egypt Appl. Sci. 20(12): 734-747. 
Bhardwaj, M.L., R.S. Ratan and U.K. Kohli. 1991. Effect of nitrogen, phosphorous and depth of bulb planting on seed production in onion. J. Indian Hort. 48(3): 264-268.

Budhathoki, K., H.N. Regmi, N.G. Pradhan, P.R. Bhurtyal and D.R. Bhattarai. 2004. Effect of set planting date on off season on onion bulb production in mid hills..In: Advances of Horticultural Proceeding in Nepal. Nepal Agricultural Research Council, National Agricultural Research Institute and Horticultural Research Division, Khumaltar, Lalitpur. pp. 419-421.

Dahal, K.K. 2008. Performance of onion varieties and level of nitrogen for off season production in Chitwan and Nawalparasi districts. M. Sc. Ag. Thesis, Tribhuvan University, Institute of Agriculture and Animal Science, Rampur, Chitwan, Nepal.

Elhilo, A.H. and G.H.M. Ali. 1971. Effect of plant population and nitrogen level on seed yield of onion at Girba. Agricultural Research Corporation, Misc. Hort. Reports. 1967. pp. 73-50.

FAO. 1996. Selected indicators of food and agriculture development in Asia Pacific Region. 1985-95. Regional Office for Asia and the Pacific (RAP), FAO, UN, Bangkok. pp. 412-414.

Farag, I.A. and S.O. Koriem. 1996. Influence of size and cutting mother bulbs on yield and quality of onion seeds. J. Assiut. Agric. Sci. 27: 97-106.

Hussain, S.W., M. Ishtiaq and S.A. Hussain. 2001. Effect of different bulb sizes and planting dates on green leaf production of onion (Allium cepa L.). J. Pakistan Biol. Sci. 1: 345-347.

Jilani, M.S. 2004. Studies on the management strategies for bulb and seed production of different cultivars on onion (Allium cepa L.). Ph.D. Thesis, Dept. of Hort., Fac. of Agric., Gomal Univ., Pakistan.

Khan, M.A., M.K. Hassan, R. Ara, M.M. Alam and S. Brahma. 2005. Effect of bulb size and harvesting time on the growth and yield of onion. Prog. Agric. 16: 25-29.

Kumar, H., J.V. Singh, K. Ajay, S. Mahak, A. Kumar and M. Singh. 1998. Studies on the influence of nitrogen on growth and yield of onion cv. Panta Red. J. Indian Agric. Res. 32: 88-92.

Levy, D., Z. Ben-Herut, N. Albasel, F. Kaisi and I. Manasra. 1981. Growing onion seeds in an arid region:drought tolerance and the effect of bulb weight, spacing and fertilization. J. Hort. Sci.14: 1-7.

Mirshekari, B., M. Mobasher and A. Biroonara. 2008. Determination of the best sowing time, bulb diameter and intra-row spacing of Azarshahr Red Onion, a new variety in Iran. Acta Hort. 771: 115-117.

Mishra, H.P. 1994. Effect of Nitrogen and Potassium on onion seeds production in calcareous soil. Hort. Abts. 65(9): 8898.

Mosleh ud-Deen, M.D. 2008. Effect of mother bulb size and planting time on growth, bulb and seed yield of onion. J. Bangladesh Agri. Res. 33(3): 531-537.

Nehra, B.K., M.L. Pandita, S. Kriti and K. Singh. 1989. Cultural and nutritional studies in relation to seed production in onon (Allium cepa L.). J. Haryana Hort. Sci. 17(1-2): 106-110.

Nepal Foreign Trade Stastics. 2009. Vegetable import statistics. Trade and Export Promotion Centre, Pulchowk, Lalitpur Nepal. pp. 526-535.

Nourai, A.H., E.M. El Fahal and A. S.Maximous. 2003. Effects of mother bulb size, plant population, nitrogen nutrition and frequency of irrigation on seed yield and seed yield components of the red onion (Allium cepa L.) in the arid tropics of northern Sudan. Proceedings of the Crop Husbandry Committee, 16-17 June, 2003, ARC. Wad Medani, Sudan. P. 965-972.

Patel, Z.G. and M.U. Vachhani. 1994. Effect of NPK fertilization on the yield and quality of onion. Hort. Absts. 65(8): 6950.

Pathak, C.P. 1994. Allium improvement for the tropics: Problems and AVRDC Strategy. In: D. J. Midmore (ed.). Acta Horticulture. International Symposium on Alliums for the Tropics, Bangkok, Chiangmai, Thailand 15-19 February 1993. Asian Regional Center AVRDC. 421p.

Rahim, M.A., M.A. Hakim and M.M. Rahman. 1997. Effect of nitrogen and potash on the yield of onion seed. J. Bangladesh Sci. Ind. Res. 32(2): 322-325.

Shakya, S. 2009. Effect of plant population on bulb size and yield of marketable bulb of onion varieties during off season. M. Sc. Ag. Thesis, Tribhuvan University, Institute of Agriculture and Animal Science, Rampur, Chitwan, Nepal.

Thapa, G.B. and D. Paudyal. 2000. Nepal. In: Mubrik Ali (ed.) Dynamics of Vegetable Production, Distribution and Consumption in Asia. Kalyani Publishers, India. P. 231-270. 